\title{
Specification of the Okadaic Acid Equivalent for Okadaic Acid, Dinophysistoxin-1, and Dinophysistoxin-2 Based on Protein Phosphatase 2A Inhibition and Cytotoxicity Assays Using Neuro 2A Cell Line
}

\author{
Tsuyoshi Ikehara ${ }^{1, *}$, Kazuya Chikanishi ${ }^{1}$ and Naomasa Oshiro ${ }^{2}$ (D) \\ 1 Course of Resource Management and Food Science, Graduate School of Fisheries Science, \\ National Fisheries University, 2-7-1 Nagata-honmachi, Shimonoseki 759-6595, Yamaguchi, Japan; \\ k220821@d.fish-u.ac.jp \\ 2 National Institute of Health Sciences, 3-25-26 Tonomachi, Kawasaki 210-9501, Kanagawa, Japan; \\ n-oshiro@nihs.go.jp \\ * Correspondence: ikehara@fish-u.ac.jp
}

\section{check for} updates

Citation: Ikehara, T.; Chikanishi, K.; Oshiro, N. Specification of the Okadaic Acid Equivalent for Okadaic Acid, Dinophysistoxin-1, and Dinophysistoxin-2 Based on Protein Phosphatase 2A Inhibition and Cytotoxicity Assays Using Neuro 2A Cell Line. J. Mar. Sci. Eng. 2021, 9, 1140. https://doi.org/10.3390/ jmse 9101140

Academic Editor: Pedro Reis Costa

Received: 16 September 2021

Accepted: 13 October 2021

Published: 17 October 2021

Publisher's Note: MDPI stays neutral with regard to jurisdictional claims in published maps and institutional affiliations.

Copyright: (c) 2021 by the authors. Licensee MDPI, Basel, Switzerland. This article is an open access article distributed under the terms and conditions of the Creative Commons Attribution (CC BY) license (https:/ / creativecommons.org/licenses/by/ $4.0 /)$.

\begin{abstract}
Diarrhetic shellfish poisoning (DSP) is a globally occurring disease threatening public health and trade. The causative toxins, okadaic acid (OA), dinophysistoxin-1 (DTX1), and dinophysistoxin-2 (DTX2) are collectively called OAs, and are quantified using the LC-MS/MS method. The hazardous effect of total OAs is expressed as the sum of OA equivalents defined for respective OAs based on mouse lethality, produced by either intraperitoneal (OAip) or oral administration (OAor). OAs are potent inhibitors of protein phosphatase 2A (PP2A) and are cytotoxic, necessitating expansion of the concept of OA equivalents to all relevant bioactivities. In this study, we determined OA equivalents for respective OA members in PP2A inhibition and cytotoxicity assays. To secure result credibility, we used certified OAs, reference materials, and PP2A produced using genetic engineering. The relative ratio of the OA equivalents determined by PP2A inhibition assays for OA, DTX1, and DTX2 were 1.0:1.6:0.3, while the ratio determined using the cytotoxicity assays indicated 1.0:1.5:0.5. OA equivalents showed a similar tendency in the PP2A inhibition and cytotoxicity assays, and matched better with oral toxicity data than intraperitoneal toxicity in mice. The PP2A inhibition assay, which measures the core activity of the OAs, suggested a higher OA equivalent for DTX1 than that currently used.
\end{abstract}

Keywords: DSP toxins; PP2A inhibition assay; OA equivalent; PP2A inhibition equivalent (OApp2a); neuro-2a toxicity equivalent (OAn2a)

\section{Introduction}

Okadaic acid (OA), dinophysistoxin-1 (DTX1), and dinophysistoxin-2 (DTX2) (Figure 1), collectively called OA-group toxins (OAs) due to their structural similarities, are a group of lipophilic natural marine toxins produced by the dinoflagellates Dinophysis spp. and Prorocentrum spp. [1-4]. These dinoflagellates are distributed worldwide and cause diarrhetic shellfish poisoning (DSP) [5]. On top of this diarrheagenicity [6], the health risks due to OAs are aggravated by their potential tumor-promoting activity [7]. The wide geographic distribution, frequent occurrence, and significant health risks, including potential tumor promotion, have made DSP one of the top issues in seafood safety. Hence, discovering accurate methods to assess the quantity and potency of the respective OAs have become an urgent social task. Presently, three methods exist to assess the harmful effects of OAs. Mouse bioassays (MBA) are based on lethality by intraperitoneal (i.p.) injection or by oral administration. The cell bioassays measure the viability of cultured cells, typically the neuro-2a cells [8]. The protein phosphatase inhibition assay is based on the strong and specific action of OA in inhibiting PP2A $[9,10]$. The traditionally used MBA is no longer 
in use because of its lack of accuracy, sensitivity, and regard for animal welfare [11,12]. The LC-MS/MS method, developed as an alternative to MBA, quantifies the OAs with high accuracy [11] but must evaluate the hazardous effects using the OA equivalent that was defined for respective OAs based on mouse lethality measured by either i.p. or oral administration, abbreviated as OAip and OAor, respectively. Thus, the total OA equivalents are used to judge the suitability of shellfish under the current regulatory system $(0.16 \mu \mathrm{g}$ OA equivalent/g whole meat) [12,13]. In the LC-MS/MS method, the reference toxins are used for calibration. The OA equivalents currently recommended for OA, DTX1, and DTX2 are 1.0, 1.0, and 0.6, respectively [14], or 1.0, 1.0, and 0.5 for OA, DTX1, and DTX2, as recommended by FAO/WHO [15]. Recently, based on the acute toxicity of oral administration, the OA equivalents (OAor) were proposed to be 1.0, 1.5, and 0.3 for OA, DTX1, and DTX2, respectively [16]. The OA equivalent recommended for DTX1, however, is considered arguable, because DTX1 was reported to be more toxic than OA in some studies [1,17]. Along with mouse lethality, the strong and specific activity of OAs in inhibiting PP2A can be cited as an important issue because of its potential implication in tumor promotion $[5,18]$. Thus, we evaluated OA equivalents using the PP2A inhibition assays that colorimetrically measure hydrolysis of $p$-nitrophenyl phosphate ( $p$-NPP) [19-21]. To ensure the high quality of the enzyme, we produced recombinant PP2A (rPP2A) using a baculovirus expression system in High Five insect cells [22,23] and constructed a rapid test kit. The enzyme rPP2A exhibited excellent stability and sensitivity for detecting and quantifying OAs in shellfish $[24,25]$. The OA equivalent was assessed using standard curves prepared using reference OA. To standardize the evaluation, we proposed the use of inhibition equivalent (OApp2a) defined for respective OAs based on the $50 \%$ inhibitory concentration $\left(\mathrm{IC}_{50}\right)$ values. The third activity to be incorporated into the concept of the OA equivalent is the potent cytotoxicity that the OAs exerts. Shellfish can be tested for OAs using a cell-based bioassay, typically using the neuro-2a cells, and can be judged by the OA equivalents (OAn2a) deduced from the $50 \%$ effective concentration $\left(\mathrm{EC}_{50}\right)$ values [26].

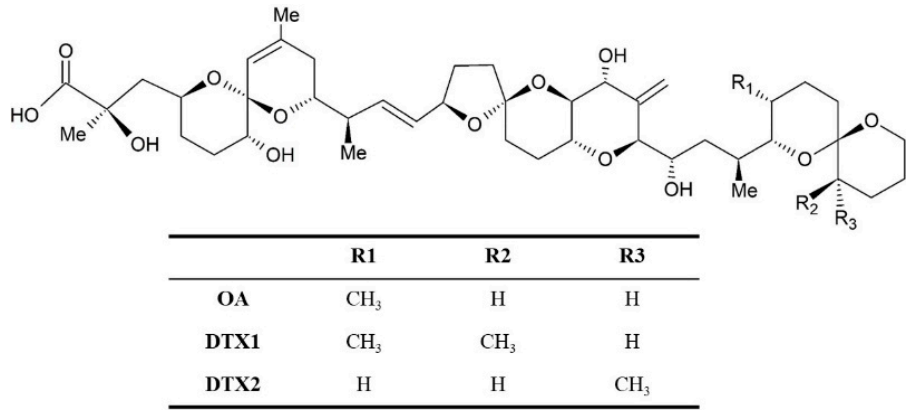

Figure 1. Chemical structure of OA, DTX1, and DTX2.

\section{Materials and Methods}

\subsection{Certified Reference Materials}

Five types of certified reference materials, CRM-OA-d, CRM-DTX1-b, CRM-DTX2b, CRM-DSP-Mus-c, and CRM-Zero-Mus, were purchased from the National Research Council (Canada). The certified concentration for CRM-OA-d, CRM-DTX1-b, and CRMDTX2-b were described as $10.4 \pm 0.5,10.4 \pm 0.8$, and $4.7 \pm 0.3 \mu \mathrm{mol} / \mathrm{L}$, respectively. Stock solutions of these CRMs were diluted according to the process in Tables S1-S6 for use in the PP2A inhibition and neuro-2a cell viability assays. The certified concentrations (as free acid) for okadaic acid and dinophysistoxins in CRM-DSP-Mus-c were as follows: OA = $1.07 \pm 0.08 \mathrm{mg} / \mathrm{kg}$, DTX1 $=1.07 \pm 0.11 \mathrm{mg} / \mathrm{kg}$, DTX2 $=0.86 \pm 0.08 \mathrm{mg} / \mathrm{kg}$. The total posthydrolysis concentrations for fatty acid acyl esters of okadaic acid and dinophysistoxins in CRM-DSP-Mus-c were as follows: OA $=2.4 \mathrm{mg} / \mathrm{kg}$, DTX1 $=1.1 \mathrm{mg} / \mathrm{kg}$, DTX2 $=2.2 \mathrm{mg} / \mathrm{kg}$. CRM-Zero-Mus was used as a matrix blank for the analysis of DSP toxins. 


\subsection{Sample Preparation for PP2A Inhibition Assay from CRM-DSP-Mus-c and CRM-Zero-Mus}

Each 2-g portion of CRM-DSP-Mus-c and CRM-Zero-Mus was extracted by Polytron homogenizer with $18-\mathrm{mL} 90 \%$ methanol at room temperature for $1 \mathrm{~min}$. The homogenate was centrifuged at $2500 \times g$ for $10 \mathrm{~min}$. The supernatant (extract) of CRM-DSP-Mus-c was diluted with the extract of CRM-Zero-Mus to the concentrations shown in Table S7. Then, the preparation of the test solutions for the assay was performed according to the method in our previous report [24] as follows: a $50-\mu \mathrm{L}$ portion of the diluted extract was diluted with $950-\mu \mathrm{L}$ sample dilution buffer $(10 \% \mathrm{EtOH}, 0.5 \%$ Tween 60 in TE Buffer) to make a test solution for PP2A inhibition assay. A $50-\mu \mathrm{L}$ portion of the test solution was used for assaying unhydrolyzed samples. Hydrolysis and neutralization of the extract were conducted as described previously [24]. The OA content in the hydrolyzed samples was calculated using a multiplying factor of 1.4 to calibrate the volume increase due to the additions of alkali and acid solutions.

\subsection{PP2A Inhibition Assay}

rPP2A was synthesized in insect cells (High Five; Invitrogen, Carlsbad, CA, USA) by infecting recombinant baculoviruses encoding $\mathrm{His}_{\mathbf{x}}$-tagged human PP2Ac $\alpha$ using a baculovirus expression system and purified as described previously [22,23]. The PP2A inhibition assay using rPP2A was conducted in a 96-well microplate as described previously [24]. The details were as follows: Each well contained $50-\mu \mathrm{L}$ test solution and $100-\mu \mathrm{L}$ $p$-nitrophenyl phosphate ( $p$-NPP; $3 \mathrm{mM}$ final concentration). The three or six wells per each test sample were used in the PP2A assay. The reaction was started by the addition of 100 $\mu \mathrm{L}$ (0.08 units) of the rPP2A, and continued for $30 \mathrm{~min}$ at $36^{\circ} \mathrm{C}$. The hydrolysis of $p$-NPP to $p$-nitrophenol ( $p$-NP) was recorded using a microplate reader (iMark; Bio-Rad Laboratories, Inc., California, CA, USA) at $405 \mathrm{~nm}$ against $490 \mathrm{~nm}$ as a reference. The PP2A activity (\%) using sample dilution buffer as a control (100\% PP2A activity) was calculated using the following equation:

$$
\text { PP2A activity }(\%)=\left(\mathrm{A} 1_{\mathrm{T}} / \mathrm{A} 1_{\mathrm{C}}\right) \times 100
$$

where $\mathrm{A} 1_{\mathrm{T}}$ is the absorbance of test solution, and $\mathrm{A} 1_{\mathrm{C}}$ is the absorbance of the control. The dose-dependent curves for the inhibition of rPP2A activity by OAs were constructed using a 4-parameter curve-fitting program (Microplate Manager 6 software, Bio-Rad Laboratories, Inc., California, CA, USA). The limit of detection (LOD = the mean of matrix blanks $+3 \mathrm{SD}$ ) and the limit of quantitation (LOQ = the mean of matrix blanks $+10 \mathrm{SD}$ ) were calculated from six measurements of the unhydrolyzed and hydrolyzed matrix blanks prepared from mussel CRM (CRM-Zero-Mus) as described previously [24].

\subsection{Neuro-2a Cell Culture, Okadaic Acids Exposure, and Cell Viability Assay}

Neuroblastoma neuro-2a cells (ECACC:89121404) were purchased from DS PHARMA BIOMRDOCAL (Japan), and cultured in RPMI-1640 medium (R8758; Sigma-Aldrich, MO, USA) supplemented with 10\% $(v / v)$ fetal bovine serum (FBS, 2916754; MP Biomedicals, Irvine, CA, USA), $1 \%(v / v), 100-\mathrm{mM}$ sodium pyruvate solution (S8636; Sigma-Aldrich, St. Louis, MO, USA), and 1\%(v/v) Penicillin-Streptomycin Solution $(\times 100)(168-23191$; FUJIFILM Wako Pure Chemical Corporation, Osaka, Japan). The cell line was routinely maintained at $37{ }^{\circ} \mathrm{C}$ in a humidified atmosphere containing $5 \% \mathrm{CO}_{2}$, and sub-cultured after reaching approximately $70 \%$ confluence. For experiments, cells were seeded in a 96-well microplate in RPMI-1640 medium (5\% FBS, 1-mM sodium pyruvate, $1 \%$ PenicillinStreptomycin Solution) at $2.5 \times 10^{4}$ cells per well. Cells were incubated $24 \mathrm{~h}$ before exposure to OAs in the same temperature and humidified atmosphere as described for cell maintenance. After growing the cells for $24 \mathrm{~h}$, exposure to increasing concentrations of OA, DTX1, and DTX2 was conducted in sextuplicate in $100-\mu \mathrm{L}$ medium for $24 \mathrm{~h}$. The six wells per test sample were used in the neuro-2a assay. At the end of the exposure time, cell viability was measured as described below. The cytotoxicity assay was performed using the Cell Titer $96 \mathrm{AQ}_{\text {ueous }}$ One solution Cell Proliferation Assay System (MTS assay; Promega, Madison, WI, USA), according to the manufacturer's protocols. After exposing 
the cells to OAs for $24 \mathrm{~h}$, the medium from the cells was removed. Then, $120-\mu \mathrm{L}$ Cell Titer 96AQueous One solution reagent mixture with RPMI-1640 medium (5\% FBS, 1-mM sodium pyruvate, $1 \%$ Penicillin-Streptomycin Solution) was added to each well. After incubation for $2 \mathrm{~h}$ at $37^{\circ} \mathrm{C}$ in a humidified atmosphere containing $5 \% \mathrm{CO}_{2}$, absorbance values were read on a microplate reader (iMark; Bio-Rad Laboratories, Inc., California, CA, USA) at 490 $\mathrm{nm}$. RPMI-1640 medium was used as a control (100\% cell viability). The cell viability (\%) was calculated using the following equation:

$$
\text { cell viability }(\%)=\left(\mathrm{A}_{\mathrm{T}} / \mathrm{A} 2_{\mathrm{C}}\right) \times 100
$$

where $\mathrm{A}_{\mathrm{T}}$ is the absorbance of test solution, and $\mathrm{A} 2_{\mathrm{C}}$ is the absorbance of the control. The dose-dependent curves for cytotoxicity by $\mathrm{OAs}$ were constructed using a 4-parameter curvefitting program (Microplate Manager 6 software, Bio-Rad Laboratories, Inc., California, CA, USA).

\section{Results}

\subsection{Inhibitory Potency on PP2A Activity and Neuro-2a Cytotoxicity of OA, DTX1, and DTX2}

OA equivalents for OA, DTX1, and DTX2 were determined by performing the PP2A inhibition assay [24]. As shown in Figure 2, the OAs inhibited the rPP2A activity in a dose-dependent manner at concentrations ranging from $0.001 \mathrm{nM}$ to $40 \mathrm{nM}$. The $\mathrm{IC}_{50}$ values deduced from these curves were $0.14,0.09$, and $0.45 \mathrm{nM}(0.11,0.07$, and $0.36 \mathrm{ng} / \mathrm{mL})$ for OA, DTX1, and DTX2, respectively. Therefore, the relative ratios for these three OAs were calculated to be 1.0:1.56:0.311 (Table 1). The figures can be rounded to 1.0:1.6:0.3.
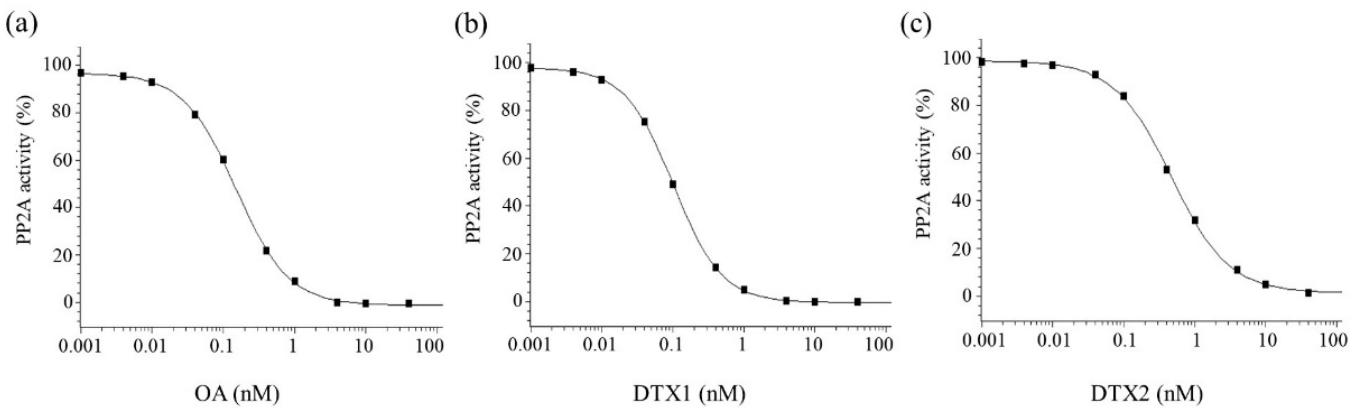

Figure 2. Dose-dependent curves for the inhibition of rPP2A activity by OA (a), DTX1 (b), and DTX2 (c). Each point represents the mean $(n=6)$ with an intra-plate SD of less than $2 \%$.

Table 1. $\mathrm{IC}_{50}$ values of $\mathrm{OAs}$ in the PP2A inhibition assay, $\mathrm{EC}_{50}$ values of $\mathrm{OAs}$ in the neuro-2a assay, and comparison of OA equivalents for OAs based on the PP2A inhibition, cytotoxicity, and mouse lethality.

\begin{tabular}{ccccccc}
\hline \multirow{2}{*}{ Toxins } & \multicolumn{2}{c}{ PP2A Inhibition } & \multicolumn{2}{c}{ Cytotoxicity } & \multicolumn{2}{c}{ Mouse Lethality } \\
\cline { 2 - 7 } & $\mathbf{I C}_{\mathbf{5 0}}$ (nM) & OApp2a $^{\mathbf{a}}$ & $\mathbf{E C}_{\mathbf{5 0}}(\mathbf{n M})$ & OAn2a $^{\mathbf{b}}$ & OAip $^{\mathbf{c}}$ & OAor $^{\mathbf{d}}$ \\
\hline OA & 0.14 & 1 & 21.6 & 1 & 1 & 1 \\
DTX1 & 0.09 & 1.6 & 14.1 & 1.5 & 1 & 1.5 \\
DTX2 & 0.45 & 0.3 & 41.0 & 0.5 & 0.5 & 0.3 \\
\hline
\end{tabular}

a OA equivalent (OApp2a) based on PP2A inhibition activity in this study. ${ }^{\mathrm{b}}$ OA equivalent (OAn2a) based on cytotoxicity to neuro-2a cells in this study. ${ }^{\mathrm{c}}$ OA equivalent (OAip) based on acute intraperitoneal toxicity in mice [15]. ${ }^{\mathrm{d}}$ OA equivalent (OAor) based on acute oral toxicity in mice [16].

The cytotoxicity of these toxins was determined by the viability assays using certified OAs and mouse neuroblastoma neuro-2a cells. As shown in Figure 3, OA, DTX1, and DTX2 were cytotoxic to neuro-2a cells in a dose-dependent manner at concentrations ranging from 1 to $300 \mathrm{nM}$ for OA and DTX1, and 1 to $200 \mathrm{nM}$ for DTX2. The $\mathrm{EC}_{50}$ values $(\mathrm{nM})$ obtained from these curves were found to be 21.6, 14.1, and $41.0 \mathrm{nM}(17.5,11.5$, and 
$33.2 \mathrm{ng} / \mathrm{mL}$ ) for OA, DTX1, and DTX2, respectively. Therefore, the relative ratio for the three OAs was calculated to be 1.0:1.53:0.53, or 1.0:1.5:0.5 in round numbers (Table 1).

(a)

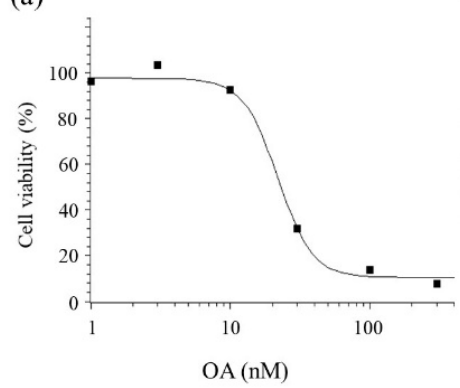

(b)

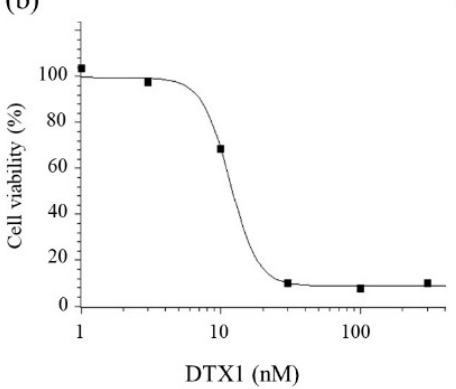

(c)

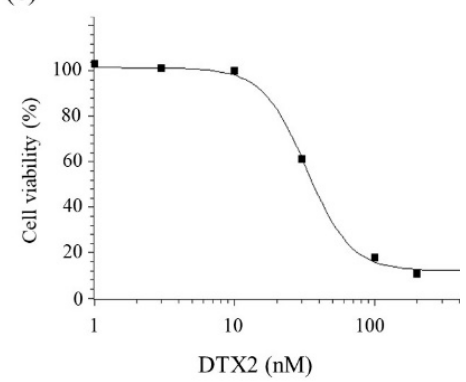

Figure 3. Effect of OA (a), DTX1 (b), and DTX2 (c) on the viability of neuro-2a cells. Each point represents the mean $(\mathrm{n}=6)$ with an intra-plate SD of less than $11 \%$.

Comparative activity data for the OAs examined by PP2A inhibition (OApp2a) and cytotoxicity assays (OAn2a), are shown in Table 1, with the mouse lethality data in the literature obtained by intraperitoneal (OAip) and oral administration (OAor). The relative bioactivity observed by PP2A inhibition and cytotoxicity assays matched better with the oral mouse toxicity than the intraperitoneal toxicity.

\subsection{Validation of OA Equivalents Obtained through PP2A Inhibition Assay Using Reference Shellfish Tissue}

To explore the compatibility between OA equivalents produced by the PP2A inhibition assay and the mouse toxicity data, we conducted the PP2A inhibition assay using certified mussel tissues (CRMs, CRM-Zero-Mus, and CRM-DSP-Mus-c). The 7-O-acyl OA and 7-O-acyl DTX1, collectively called DTX3, were subjected to hydrolysis as officially recommended [14]. The quantifiable range in the PP2A inhibition assay was assessed from the calibration curve prepared with CRM of certified concentrations of OA (CRM-OA-d). From the calibration curve shown in Figure 4, the quantifiable range was deduced to lie between 0 and $-10 \mathrm{ng} / \mathrm{mL}$. The LOD values were $0.0387 \mu \mathrm{g} / \mathrm{g}$ (unhydrolyzed) and $0.0646 \mu \mathrm{g} / \mathrm{g}$ (hydrolyzed), and the LOQ values were $0.0765 \mu \mathrm{g} / \mathrm{g}$ for unhydrolyzed and $0.0989 \mu \mathrm{g} / \mathrm{g}$ for hydrolyzed samples (Table 2). For calculating the total OA equivalent of hydrolyzed samples, a factor (1.4) was used to calibrate the value increase due to the added alkali and acid solutions. Therefore, the two limits (LOQ and LOD) were slightly higher with hydrolyzed samples. Consequentially, the values in the hydrolyzed blanks were slightly higher than those before hydrolysis, but were still low enough to ensure the detection and quantification of $\mathrm{OA}$ at the regulation level $(0.16 \mu \mathrm{g} / \mathrm{g}$ whole meat) $[12,13]$. Thus, the assay can detect and quantify OA at a much lower level than requested by the regulation.

Table 2. Limits of detection (LOD) and quantitation (LOQ) for Mussel.

\begin{tabular}{ccc}
\hline \multirow{2}{*}{ Matrix } & \multicolumn{2}{c}{ Mussels } \\
\cline { 2 - 3 } & Unhydrolyzed & Hydrolyzed \\
\hline Mean ${ }^{\mathrm{a}}(\mu \mathrm{g} / \mathrm{g})$ & 0.0225 & 0.0499 \\
$\mathrm{SD}$ & \pm 0.0054 & \pm 0.0049 \\
$\mathrm{LOD}^{\mathrm{b}}(\mu \mathrm{g} / \mathrm{g})$ & 0.0387 & 0.0646 \\
$\mathrm{LOQ}^{\mathrm{c}}(\mu \mathrm{g} / \mathrm{g})$ & 0.0765 & 0.0989 \\
\hline
\end{tabular}

${ }^{\mathrm{a}}$ Mean value of 6 independent matrix blanks prepared from mussel CRM (CRM-Zero-Mus). ${ }^{\mathrm{b}}$ Mean value $+3 \times$ SD. ${ }^{\mathrm{c}}$ Mean value $+10 \times \mathrm{SD}$. 


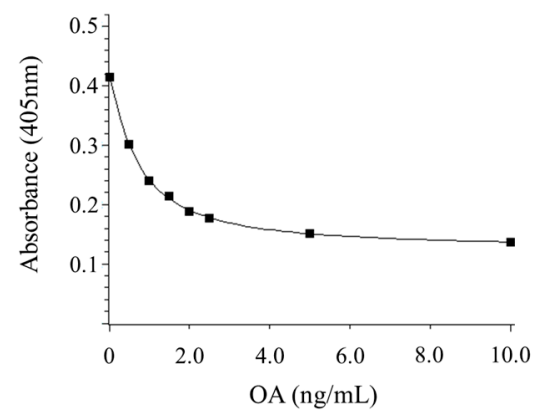

Figure 4. The calibration curve was obtained using the PP2A inhibition assay. The PP2A inhibition assay was conducted with OA standard solutions (0, 0.5, 1.0, 1.5, 2.0, 2.5, 5.0, and $10.0 \mathrm{ng} / \mathrm{mL})$ prepared from OA CRM (CRM-OA-d). Each point represents the mean $(n=3)$ with an RSD of less than $2.5 \%$.

To evaluate the accuracy of the assay method, we conducted the PP2A inhibition assay on the certified mussel tissue (CRM-DSP-Mus-c). The resultant OA equivalents based on the PP2A inhibition assays were compared with OA equivalents (Table S8) expected according to the OApp2a shown in Table 1 and the OA concentrations shown in Table S7 (Table 3). The assessment using the OA equivalent values led to slight but consistent overestimation of the contents, and RSD obtained from five separate experiments was 1.7-7.8\%. The OA equivalents calculated using the PP2A inhibition assay were 90.3-116.1\%. These data, produced using certified material, rather than spiked recovery tests, confirmed the reliability of the PP2A inhibition assay using rPP2A as the method for detecting and quantifying OAs in shellfish.

Table 3. OA equivalents ( $\mu$ g of OA eq / $g$ whole meat) determined by PP2A inhibition assay and expected according to the OApp2a.

\begin{tabular}{|c|c|c|c|c|}
\hline \multirow{3}{*}{$\begin{array}{l}\text { Sample } \\
\text { no. }\end{array}$} & \multicolumn{3}{|c|}{ OA Equivalents ( $\mu \mathrm{g} / \mathrm{g}$ ) } & \multirow[t]{3}{*}{$\begin{array}{c}\text { Accuracy } \\
(\%)(a) /(b) \times 100\end{array}$} \\
\hline & \multicolumn{2}{|c|}{$\begin{array}{l}\text { PP2A Inhibition Assay Result } \\
\text { in the Present Study (a) }\end{array}$} & \multirow{2}{*}{$\begin{array}{l}\text { Expected Equivalent * } \\
\text { according to the OApp2a (b) }\end{array}$} & \\
\hline & Mean & RSD (\%) & & \\
\hline 1 & 0.5487 & 5.6 & 0.6080 & 90.3 \\
\hline 2 & 0.3282 & 3.6 & 0.3040 & 108.0 \\
\hline 3 & 0.1733 & 7.8 & 0.1507 & 115.0 \\
\hline 4 & 0.5293 & 2.4 & 0.4820 & 109.8 \\
\hline 5 & 0.2798 & 6.4 & 0.2410 & 116.1 \\
\hline 6 & 0.1332 & 1.7 & 0.1213 & 109.8 \\
\hline
\end{tabular}

\section{Discussion}

In this study, we determined the potency of the OAs to inhibit PP2A activity (OApp2a) and suppress cell viability (OAn2a) using certified reference material. The PP2A inhibitory potency expressed in $\mathrm{IC}_{50}$ decreased by order of DTX1 > OA $>$ DTX2. This order agreed with that defined by acute oral toxicity in mice. The neuro-2a cell viability assays also gave the same order as the OAs. The relative ratio for the three OAs cytotoxicity shown in Table 1 was similar to the results of previous report [8]. Previously, the lethal potencies of OA and DTX1 by intraperitoneal injection were reported, respectively, to be $200 \mu \mathrm{g} / \mathrm{kg}$ [1] and $160 \mu \mathrm{g} / \mathrm{kg}$ [17]. The higher toxicity of DTX1 compared to OA agrees with the results of this study, and suggests the necessity of reevaluating the relative potency of OAs, currently assumed as OA:DTX1 being 1:1.

In the LC-MS analysis, dinophysistoxin-3 (DTX3), the 7-O-acyl esters of OA, and DTX1 are quantified after hydrolysis to OA or DTX1. In the MBA and cytoxicity assays, however, the fatty acids, either present originally or produced by hydrolysis, significantly interfere with the assays, sometimes giving false-positive results [14]. In addition to fatty acids, other concurrent toxins called pectenotoxins (PTX) or yessotoxins (YTX) also produce 
false-positive results. Therefore, sample preparations for MBA require careful attention to the contaminant fatty acids and other toxins (PTX and YTX). Alternatively, the PP2A inhibition assay is insensitive to the contaminant fatty acids PTXs, and YTXs, providing a distinct advantage over other assays [20]. The data in this study were obtained using certified toxins or materials and rPP2A of high quality. The PP2A assays, along with LC/MS analysis, can determine microcystins besides OAs [27,28]. The assay is simple, inexpensive, ready for use on site, and can handle a large number of samples [29]. This assay method is suitable for broad use as a replacement for MBA, as supported by the consistency with the oral toxicity of MBA.

Supplementary Materials: The following are available online at https://www.mdpi.com/article/10 .3390/jmse9101140/s1. Table S1: Dilution of CRM-OA-d $(10.4 \mu \mathrm{M})$ for PP2A inhibition assay; Table S2: Dilution of CRM-DTX1-b (10.4 $\mu \mathrm{M})$ for PP2A inhibition assay; Table S3: Dilution of CRM-DTX2-b $(4.7 \mu \mathrm{M})$ for PP2A inhibition assay; Table S4: Dilution of CRM-OA-b $(10.4 \mu \mathrm{M})$ for neuro-2a cell viability assay; Table S5: Dilution of CRM-DTX1-b $(10.4 \mu \mathrm{M})$ for neuro-2a cell viability assay; Table S6: Dilution of CRM-DTX2-b $(4.7 \mu \mathrm{M})$ for neuro-2a cell viability assay; Table S7: OAs concentration in diluted CRM-DSP-MUS-c for PP2A inhibition assay; Table S8: Total OA equivalents ( $\mu \mathrm{g} / \mathrm{g}$ whole meat) expected according to the OApp2a shown in Table 1 and the OA concentrations shown in Table S7.

Author Contributions: T.I. and N.O. conceived and designed the experiments; T.I. and K.C. performed the experiments and analyzed the data; T.I. and K.C. contributed reagents/materials/analysis tools; and T.I., K.C. and N.O. wrote the manuscript. All authors have read and agreed to the published version of the manuscript.

Funding: This research received no external funding.

Institutional Review Board Statement: Not applicable.

Informed Consent Statement: Not applicable.

Data Availability Statement: Not applicable.

Acknowledgments: We thank Takeshi Yasumoto (Japan Food Research Laboratories) for the valuable conversation and for critically reading this manuscript.

Conflicts of Interest: The authors declare no conflict of interest.

\section{References}

1. Murakami, Y.; Oshima, Y.; Yasumoto, T. Identification of okadaic acid as a toxic component of a marine dinoflagellate Prorocentrum lima. Bull. Jpn. Soc. Sci. Fish. 1982, 48, 69-72. [CrossRef]

2. Hu, T.; Doyle, J.; Jackson, D.; Marr, J.; Nixon, E.; Pleasance, S.; Quilliam, M.A.; Walter, J.A.; Wright, J.L.C. Isolation of a new diarrhetic shellfish poison from irish mussels. J. Chem. Soc. Chem. Commun. 1992, 1, 39-41. [CrossRef]

3. Lee, J.-S.; Igarashi, T.; Fraga, S.; Dahl, E.; Hovgaard, P.; Yasumoto, T. Determination of diarrhetic shellfish toxins in various dinoflagellate species. J. Appl. Phycol. 1989, 1, 147-152. [CrossRef]

4. Yasumoto, T.; Oshima, Y.; Sugawara, W.; Fukuyo, Y.; Oguri, H.; Igarashi, T.; Fujita, N. Identification of Dinophysis fortii as the causative organism of diarrhetic shellfish poisoning. Bull. Jpn. Soc. Sci. Fish. 1980, 46, 1405-1411. [CrossRef]

5. Yasumoto, T.; Murata, M. Marine toxins. Chem. Rev. 1993, 93, 1897-1909. [CrossRef]

6. Hamano, Y.; Kinoshita, Y.; Yasumoto, T. Toxic dinoflagellates. In Proceedings of the Third International Conference on Toxic Dinoflagellates, St. Andrews, NB, Canada, 8-12 June 1985; Anderson, D.M., White, A.W., Baden, D.G., Eds.; Elsevier: New York, NY, USA, 1985; pp. 383-388.

7. Fujiki, H.; Suganuma, M.; Suguri, H.; Yoshizawa, S.; Ojika, M.; Wakamatsu, K.; Yamada, K.; Sugimura, T. Induction of ornithine decarboxylase activity in mouse skin by a possible tumor promoter, okadaic acid. Proc. Jpn. Acad. Ser. B 1987, 63, 51-53. [CrossRef]

8. Soliño, L.; Sureda, F.X.; Diogène, J. Evaluation of okadaic acid, dinophysistoxin-1 and dinophysistoxin-2 toxicity on neuro-2a, ng108-15 and mcf-7 cell lines. Toxicol. Vitr. 2015, 29, 59-62. [CrossRef]

9. Smienk, H.; Domínguez, E.; Rodríguez-Velasco, M.L.; Clarke, D.; Kapp, K.; Katikou, P.; Cabado, A.G.; Otero, A.; Vieites, J.M.; Razquin, P.; et al. Quantitative determination of the okadaic acid toxins group by a colorimetric phosphatase inhibition assay: Interlaboratory study. J. AOAC Int. 2019, 96, 77-85. [CrossRef] [PubMed]

10. Garibo, D.; Dàmaso, E.; Eixarch, H.; de la Iglesia, P.; Fernández-Tejedor, M.; Diogène, J.; Pazos, Y.; Campàs, M. Protein phosphatase inhibition assays for okadaic acid detection in shellfish: Matrix effects, applicability and comparison with lc-ms/ms analysis. Harmful Algae 2012, 19, 68-75. [CrossRef] 
11. European Commission. Commission regulation no. 15/2011 of january 10, 2011. Off. J. Eur. Communities 2011, 3-6.

12. Codex Alimentarius International Food Standards. In Standard for Live and Raw Bivalve Molluscs Codex Standard 292-2008; Adopted in 2008. Amendment: 2013. Revision: 2014 and 2015; Food and Agriculture Organization of the United Nations: Rome, Italy; World Helth Organization: Geneva, Switzerland, 2008.

13. European Commission. Regulation (ec) no 853/2004. Off. J. Eur. Union L139 2004, 47, 55-105.

14. European Food Safety Authority. Marine biotoxins in shellfish - okadaic acid and analogues-scientific opinion of the panel on contaminants in the food chain. EFSA J. 2008, 6, 589. [CrossRef]

15. FAO; WHO. Technical Paper on Toxicity Equivalency Factors for Marine Biotoxins Associated with Bivalve Molluscs; FAO: Rome, Italy, 2016; p. 47.

16. Abal, P.; Louzao, M.C.; Suzuki, T.; Watanabe, R.; Vilariño, N.; Carrera, C.; Botana, A.M.; Vieytes, M.R.; Botana, L.M. Toxic action reevaluation of okadaic acid, dinophysistoxin-1 and dinophysistoxin-2: Toxicity equivalency factors based on the oral toxicity study. Cell. Physiol. Biochem. 2018, 49, 743-757. [CrossRef] [PubMed]

17. Murata, M.; Shimatani, M.; Sugitani, H.; Oshima, Y.; Yasumoto, T. Isolation and structural elucidation of the causative toxin of the diarrhetic shellfish poisoning. Bull. Jpn. Soc. Sci. Fish. 1982, 48, 549-552. [CrossRef]

18. Bialojan, C.; Takai, A. Inhibitory effect of a marine-sponge toxin, okadaic acid, on protein phosphatases. Specificity and kinetics. Biochem. J. 1988, 256, 283-290. [CrossRef]

19. Takai, A.; Mieskes, G. Inhibitory effect of okadaic acid on the p-nitrophenyl phosphate phosphatase activity of protein phosphatases. Biochem. J. 1991, 275, 233-239. [CrossRef]

20. Tubaro, A.; Florio, C.; Luxich, E.; Sosa, S.; Loggia, R.D.; Yasumoto, T. A protein phosphatase 2a inhibition assay for a fast and sensitive assessment of okadaic acid contamination in mussels. Toxicon Off. J. Int. Soc. Toxinol. 1996, 34, 743-752. [CrossRef]

21. Simon, J.F.; Vernoux, J.P. Highly sensitive assay of okadaic acid using protein phosphatase and paranitrophenyl phosphate. Nat. Toxins 1994, 2, 293-301. [CrossRef]

22. Ikehara, T.; Nakashima, S.; Nakashima, J.; Kinoshita, T.; Yasumoto, T. Efficient production of recombinant pp2a at a low temperature using a baculovirus expression system. Biotechnol. Rep. 2016, 11, 86-89. [CrossRef] [PubMed]

23. Ikehara, T.; Shinjo, F.; Ikehara, S.; Imamura, S.; Yasumoto, T. Baculovirus expression, purification, and characterization of human protein phosphatase 2 a catalytic subunits $\alpha$ and $\beta$. Protein Expr. Purif. 2006, 45, 150-156. [CrossRef]

24. Ikehara, T.; Imamura, S.; Yoshino, A.; Yasumoto, T. Pp2a inhibition assay using recombinant enzyme for rapid detection of okadaic acid and its analogs in shellfish. Toxins 2010, 2, 195-204. [CrossRef]

25. Ikehara, T.; Kinoshita, T.; Kurokawa, A.; Nakashima, S.; Maekawa, K.; Ohshiro, N.; Yasumoto, T. Evaluation of protein phosphatase 2A (PP2A) inhibition assay for rapid detection of dsp toxins in scallop. NIPPON SUISAN GAKKAISHI 2017, 83, 367-372. [CrossRef]

26. Bodero, M.; Bovee, T.F.H.; Wang, S.; Hoogenboom, R.L.A.P.; Klijnstra, M.D.; Portier, L.; Hendriksen, P.J.M.; Gerssen, A. Screening for the presence of lipophilic marine biotoxins in shellfish samples using the neuro-2a bioassay. Food Addit. Contam. Part A 2018, 35, 351-365. [CrossRef]

27. Ikehara, T.; Kuniyoshi, K.; Yamaguchi, H.; Tanabe, Y.; Sano, T.; Yoshimoto, M.; Oshiro, N.; Nakashima, S.; Yasumoto-Hirose, M. First report of microcystis strains producing mc-fr and -wr toxins in japan. Toxins 2019, 11, 521. [CrossRef] [PubMed]

28. Deeds, J.R.; Stutts, W.L.; Celiz, M.D.; MacLeod, J.; Hamilton, A.E.; Lewis, B.J.; Miller, D.W.; Kanwit, K.; Smith, J.L.; Kulis, D.M.; et al. Dihydrodinophysistoxin-1 produced by dinophysis norvegica in the gulf of maine, USA and its accumulation in shellfish. Toxins 2020, 12, 533. [CrossRef] [PubMed]

29. Massey, I.Y.; Wu, P.; Wei, J.; Luo, J.; Ding, P.; Wei, H.; Yang, F. A mini-review on detection methods of microcystins. Toxins 2020, 12, 641. [CrossRef] [PubMed] 